\title{
The Role of Islamic Financial Institutions in Supporting Economic Growth in the Digital Era: Case Study in Indonesia
}

\author{
Ivan Rahmat Santoso', Syarwani Canon², Abd.Rahman Pakaya ${ }^{3}$ \\ \{ivanrahmatsantoso@gmail.com ${ }^{1}$, syarwanic@yahoo.com², Rahmatya_pakaya75@co.id $\left.{ }^{3}\right\}$ \\ ${ }^{1,2,3}$ Gorontalo State University, Jl. Jend. Sudirman No. 6, Dulalowo Tim., Kota Tengah, Kota Gorontalo, \\ Gorontalo, 96128, Indonesia
}

\begin{abstract}
The Islamic financial industry in the digital era must adapt to the development of financial technology to develop maximum products and services to the community. This study aims to analyze the role of Islamic financial institutions for national economic growth in the digital age. The study uses qualitative research methods with descriptive analysis techniques. The results of the study found the role of Islamic financial institutions in the digital age was maximized through strategies to improve the quality of human resources, the innovation of digital-based products and services, education and outreach and collaboration in the field of fintech. The role of Islamic financial institutions for the national economy in the digital era in terms of micro and macro through cooperation between Islamic financial institutions has implications for economic growth through indicators of the development of the real sector, reducing poverty levels by increasing people's income and reducing unemployment
\end{abstract}

Keywords: Islamic Financial Institutions, Fintech, Economic Growth, Digital Era

\section{Introduction}

The development of the digital era demands adjustments in all fields including the economy. This adjustment is anticipated by financial institutions and companies in the context of competitive competition to make it easier to achieve planned targets. [1]. In this globalization era, the Islamic economic system is seen as having a significant role to be dignified and accepted by all countries in the world dealing with global, multilateral, bilateral and international economic problems [2]. To anticipate this, Islamic financial institutions as instruments of Islamic economics need to pay attention to several supporting factors such as technological mastery, development of sharia-based small and medium-sized businesses, maintaining sharia economic excellence, namely the sharia economic system, and also the prohibition of riba [3]. Related to the mastery of sharia economic technology as part of the development of the world economy it is expected to take a role in this digital age and be able to balance the development of information and communication technology that is increasingly reaching [4]. Amrin Barata's research results [5] found that financial technology through the sharia e-commerce investment sub-sector was able to trigger national economic growth to grow by 0.048 percent or economic output increased by Rp5.08 trillion. The impact on gross value added (GVA) grew by 0.072 percent or increased by Rp3.72 trillion. Also, national-collaboration revenues increased by $\mathrm{Rp} 795.36$ billion with investments in the 
electronics sector. After additional surprises for Fintech and the trade sector, economic growth increased by 0.052 percent or Rp 5.48 trillion.

The sharia financial industry in Indonesia consists of the sharia banking industry, sharia capital markets, and sharia non-bank finance, which has been developing from year to year. Islamic banking as one of the biggest contributors to Islamic financial assets with financing products channeled able to influence the growth of the real sector and economic growth [6]. Based on data from the Financial Services Authority (OJK) as an institution that plays a role in sharia financial regulation and supervision in Indonesia shows that from 2013 to 2016 the total sharia financial assets increased, although the growth had decreased in 2014, namely growth of $18.17 \%$ if compared to 2013 which grew by $26.21 \%$ from the previous year. In December 2016, the total sharia financial assets of Indonesia (excluding sharia shares) reached Rp889.28 trillion or around USD66.2 billion (Financial Services Authority (OJK), 2017). Furthermore, the role of the Islamic finance industry is increasingly important for the national economy in meeting the demands of the public for the products and services of the Islamic financial industry, as well as to meet the needs of national development. The development of Islamic finance can contribute to developing economic potential, improve the welfare of society and the increasingly even distribution of national development cakes that automatically contribute and support contemporary Islamic strategies in reducing poverty [7], by optimizing sharia-based economic and financial development in various sectors, including trade, entrepreneurship, banking, investment, insurance and other economic development sectors for that the government should consider implementing proactive and beneficial economic and institutional policies directed at Islamic finance [8].

Islamic financial institutions which in every sharia transaction based on Islamic teachings have the momentum in the current digital era to contribute to national economic growth without being separated from the Islamic principles inherent in every economic activity. For this reason, the application of financial technology in Islamic financial institutions such as Islamic banking [9], Islamic insurance, Islamic pawnshop and other Islamic financial institutions are a necessity that must be implemented in realizing these objectives in line with the dynamics and challenges of the Islamic community in the modernization era [10]. This study aims to analyze the role and challenges of Islamic financial institutions in their role in supporting national economic growth in the digital age. Each opening of a new era adds a new dimension of economic development that was previously inactive and redefines the main inputs and outputs of the production process [11], for this reason, it is necessary to analyze opportunities and challenges and strategies in dealing with the new media.

This paper offers the novelty of the role and strategy of Islamic financial institutions in the digital era to contribute to economic growth, especially in Indonesia both at the macro level which is dominated by Islamic banking and at the micro-level such as BMT (Baitul Maal Wat Tamwil) Islamic People's Credit Banks and Financial Institutions Other Micro Sharia. Thus, this study provides new enlightenment for Islamic economic activists and the government as the executor and policymaker in increasing the role of Islamic financial institutions in the Indonesian context.

\section{Literature Review}

Previous research related to the role of Islamic financial institutions for economic growth mostly focused on Islamic banks including, the role of Islamic banks for economic growth (El-Galfy \& Khiyar, 2012; Johnson, 2013; Abduh \& Azmi Omar, 2012; Imam \& Kpodar, 2016). Meanwhile, the existing literature on digital financial technology in Islamic financial 
institutions has been discussed in several previous kinds of literature. From studies that discuss Islamic financial institutions and financial technology including (Rusydiana, 2018; Muhamad Mujahidin, 2019; Arvian Firmansyah \& Anwar, 2019). In brief, a study discussing the role of Islamic financial institutions for economic growth in the digital age has not been taken as an object of research.

\subsection{Islam and Economic Growth}

Islam defines economic growth as a continuous development of factors of production that are truly capable of contributing to welfare human (Chapra, 2019). Thus, growth economics according to Islam is laden value. An increase experienced by factors production is not considered a growth economy if the production is, for example, insert proven items bad and dangerous effect humans [20]. Economic development according to Islam it is multidimensional covers quantitative and qualitative aspects. The goal is not merely welfare material in the world, but also the welfare of the hereafter. Both according to Islam unite integrally.

Islam, basically, is very concerned with this issue of economic development. Nevertheless, economic development in Islam must guide the development of the right human line and in the right direction. In the end, economic development remains integrated and an inseparable element of the moral and socio-economic development of human society [21]. The concept of development in Islam has a comprehensive framework that includes morals, norms, values, spiritual, and material aspects. The development of Islam is also oriented towards the goal of value-oriented activities, which are aimed at optimizing the role of humans in all dimensions of life in Indonesia to achieve Falah (prosperity) both in this world and the hereafter.

\subsection{Financial Technology (FinTech)}

Financial technology, often shortened to fintech, is the technology and innovation that aims to compete with traditional financial methods in the delivery of financial services [22]. It is an emerging industry that uses technology to improve activities in finance [23]. The use of smartphones for mobile banking, investing services [24] and cryptocurrency are examples of technologies aiming to make financial services more accessible to the general public. Financial technology companies consist of both startups and established financial institutions and technology companies trying to replace or enhance the usage of financial services provided by existing financial companies. Fintech can also be considered as" directing what innovative it also improves financial processes by supporting technology solutions that are suitable for different businesses, while they can also lead to new business models or even new businesses [25]. Financial technology has been used to automate insurance, trading, banking services, and risk management [26]. The services may originate from various independent service providers including at least one licensed bank or insurer. The interconnection is enabled through open APIs and open banking and supported by regulations such as the European Payment Services Directive.

\section{Research Methods}

The research method used is a qualitative method with a descriptive analysis approach. A descriptive method is a method that functions to describe or give a description of the object under study through data or samples that have been collected as they are without analyzing and 
making conclusions that apply to the public [27]. In other words, analytical descriptive research takes the problem or focuses on the problems as they were when the research was conducted. The research results are then processed and analyzed to conclude. Sources of data obtained from secondary sources in the form of books, journals, scientific publications, and other relevant sources.

\section{Results And Discussion}

\subsection{Opportunities and Challenges of Islamic Financial Institutions in the Digital Era}

The Islamic economic system based on the Qur'an and Hadith requires the application of Syariah rules in financial management. On the other hand, Islamic economic activists have demands to introduce Islamic economics and the role of Islamic economics in Indonesia needs to be improved to support the development of Islamic economics in people's lives [28]. The digital era that is loaded with the use of Islamic economic technology through Islamic financial institutions can take advantage of opportunities to improve services to the public on the facilities of Islamic financial institutions such as ease of access and quality of services of Islamic financial institutions, leading to public satisfaction with the use of digitizing technology that can directly improve the Islamic economic track record itself.

In line with that, to support Islamic financial institutions in the digital era, the use of financial technology is absolutely necessary to compete in the digitalization era. Fintech is one of the innovations in digital financial services technology that is permissible in Islam because it brings enormous benefits and problems to the people. Fintech's presence is an alternative solution to the creation of sharia financial transactions that is easier, faster and more efficient. Besides, sooner or later with the potential and wealth of Indonesia's natural resources has the opportunity to become the center of the world's halal industry that will promote halal food, halal fashion and halal tourism to reach the Global Islamic Economy. The implementation of fintech in the Islamic banking industry will facilitate and bring business players closer, especially micro, small and medium enterprises to access Islamic financial services products offered and apply for direct financing without having to come directly to branch offices [29]. Such a model, in addition to making it easier for micro, small and medium business entrepreneurs in obtaining financial access, can also improve financial inclusion and improve the performance of Islamic banks and other Islamic financial institutions.

In terms of financing the development of Islamic financial institutions that are more reliant on the real sector to meet the needs of the community so that it requires a higher level of trust. For this reason, Islamic financial institutions should be able to utilize financial technology to accelerate the financing process. This technology is expected to facilitate service to customers in terms of financing products in Islamic banks in addition to shifting consumer preferences that affect consumer demand for innovation. Easy internet access and the ability of internet network users to do real-time transactions have encouraged high expectations, especially regarding convenience, speed, lower costs, and ease of use of financial services [30].

The challenges faced by Islamic financial institutions in the digital era are, First, with the increasing consumption patterns and behavior of people who want something easily and quickly to indirectly demand Islamic financial institutions to improve services to customers with. Satisfaction with services is a major factor to consider for sharia financial institution service businesses. In addition to improving Cybernet completeness facilities, namely services to customers via the internet, Islamic financial institutions need to apply information technology (IT) services to Islamic Microfinance Institutions to reach the poor in remote areas 
[31]. Second, the security department, with the increasingly sophisticated security technology along with the increasingly sophisticated theft technology in the digital realm. The information system developed by financial institutions, especially banks, allows them to carry out business transactions (transfers, account management, withdrawals, etc.) and at the same time, exercise control over the information exchanged (Gaumer, Mortier, \& Moutaib, 2016). More and more, information is being targeted by cyberattacks from various groups of cybercriminals. Islamic financial institutions to anticipate this can increase the supervision of internet service provider facilities, especially in applications that provide convenience for consumers who use Islamic financial institutions.

\subsection{Strategies of Islamic Financial Institutions in the Digital Era}

\subsubsection{Quality and Competency Improvement of Information Technology Resources (TI)}

One of the keys to winning competition in a turbulent vertical environment lies in the Human Resources in which the company can optimally work and be employed [33]. The utilization of technology and automation has implications for the many changes involving human resources in a company. Work environment and new technology In a company require management to be able to manage changes in three important things: employee skills and skills, continuing career paths of employees, and increasing employee productivity. The need for human resources is the most important thing to encourage literacy and increase the potential of the Islamic financial industry which is currently growing rapidly, along with the increasing demand for Islamic products. Human resources in Islamic financial institutions are expected to not only master financial technology (fintech) but also have expertise in the field of Islamic economics so that the products launched are truly by Islamic principles.

The implementation phase must be followed by a socialization phase in this case in the form of training provided to employees of Islamic financial institutions. The operation of new systems and technologies is usually aimed at increasing the company's competitiveness in the form of improving service quality, speed, accuracy, and effectiveness of organizational goals. The training becomes a means of socialization and enhancing the ability of employees, increasing motivation and increasing productivity and performance of employees of Islamic financial institutions.

\subsubsection{Digital Based Product and Service Innovation}

Innovation has a very important role in the development of the country's economy because innovative companies create new values that did not exist before. The more innovative a company is, the more productive and more efficient in using resources. The more productive a company is in a country, the more efficient the country is using resources[34]. Thus the innovations made by the company show how important innovation is not only for the benefit of the company but also for the country and also the effect of the innovation on society. The Innovation of products and services of Islamic financial institutions needs to be done to balance the digital development along with the increasingly fierce competition to attract customers and consumers. These products and services are also directed at increasing market share and benefits of Islamic Financial Institutions for the community, product innovation, both funding, and financing as well as the embodiment of less-cash society must be continuously carried out through technology. For example, Islamic banking institutions can create debit cards for payment of tolls, gas stations, and some of these products must be marketed and equipped with an excellent level of service. 


\subsubsection{Education and Outreach}

The digital era can be an opportunity for Islamic financial institutions to increase the more intensive and structured socialization and education of Islamic financial institutions. The purpose of the socialization and education carried out by Islamic financial institutions is to implement a grand strategy for the development of Islamic financial institutions to create an Indonesian society that is free of usury. One of the parameters of the effectiveness of socialization and education is the formation of a good understanding in the community about sharia financial institutions to create public confidence in using products and services of sharia financial institutions [35]. To go in that direction, all potential and capital that is already owned must be managed properly. One key is sustainable community understanding development, service innovation, and customer protection. Building and expanding people's understanding of finance and sharia-based economic business is a real impetus for improving the quality of Islamic finance in developing the national economy. The intensity of socialization and education with the financial support of technology in the digital era related to the use of Islamic financial institutions' products and services, such as banking, insurance, capital markets, mutual funds, mortgages, and Islamic cooperatives can increase the growth and resilience of regional and national economies. In addition to the socialization of the Islamic financial industry will be able to develop sustainably.

\subsubsection{Collaboration and Cooperation}

As a large country with various economic potentials, Indonesia should be able to become the center of global Islamic financial development. In order to achieve our desire to be a leader in the development of global sharia finance and take advantage of the development of the sharia financial services sector for the benefit of the nation, collaboration between ministries, government agencies and related non-governmental institutions to mutually support the development of sharia financial services sector, overcome various obstacles to the development of the sharia financial services industry in the digital era, and synergistically making various efforts to improve the efficiency and competitiveness of the sharia financial services sector. Some examples of cooperation that can be applied by Islamic financial institutions such as Islamic banking and other micro Islamic institutions: First, cooperation by publishing shadow investors or shadow investors. In this loan, Islamic banks offer to finance through financial technology companies to investors. However, the offer was not informed to investors that the planned expenditure was driven by Islamic banks. With this loan, sources obtained from investors are entered into financial technology companies. Meanwhile, the owner of the project to be financed is a related Islamic bank. Yields for financial technology companies are obtained from investor fees, while banks are obtained from project owners. Second, create an outsourcing platform which is a collaboration between Islamic banks and financial technology companies. Almost similar to the first issue, the difference only lies in more open information for investors about Islamic banks as financing promoters. By increasing the development of financial and digital technology, it can increase the distribution of Islamic bank financing and digital financing platforms independently and collectively create a consortium.

\subsubsection{The Role of Islamic Financial Institutions for Economic Growth in the Digital Age}

Strengthening the investment base based on sharia principles, as in the sharia financial industry, is expected to strengthen the structure of the national financial system as a whole, 
which can support the process of channeling funds and investing people in the provision of capital to support the process of sustainable economic development. The existence of the sharia financial system which is under the supervision of the OJK (Financial Services Authority), which has implemented risk-based arrangements will add stability to the financial system and at the same time provide services to the public's needs for sharia-based financial services that are safe and efficient. economic growth must be effective in reducing poverty. That is, growth should spread in each income group, including in the poor population (growth with equity) [36]. On the other hand, poverty is still dominated by village people who are not minimally less capable of managing technology and lack of information obtained [37].
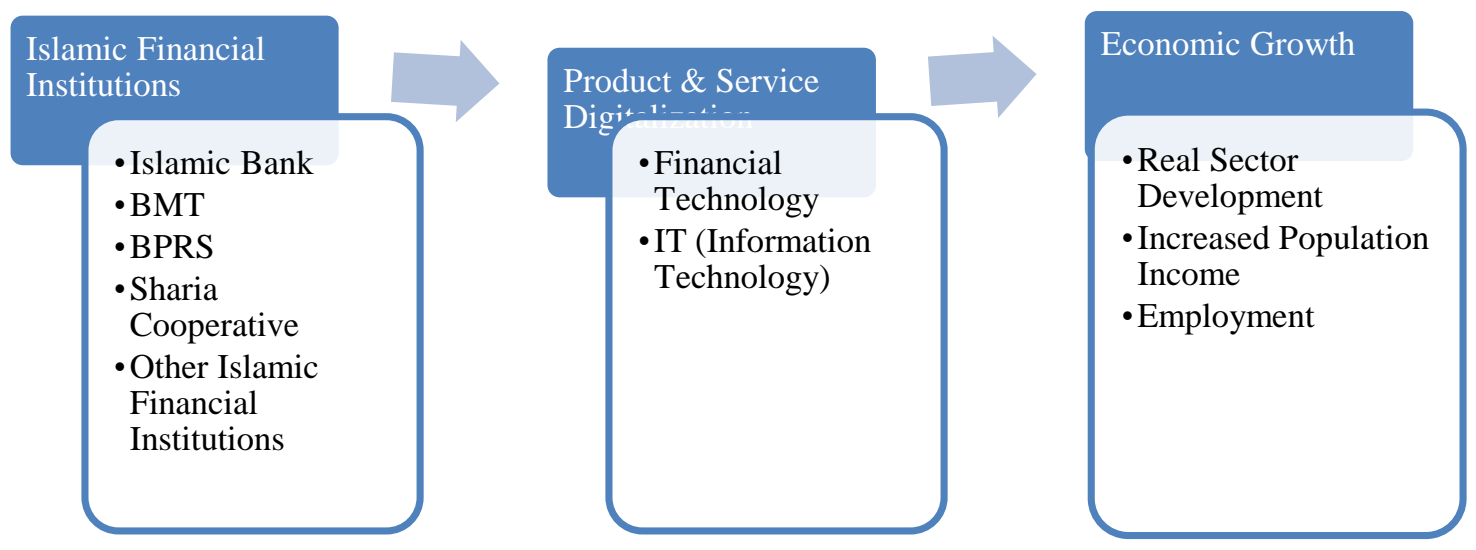

Fig. 1. Process of Islamic financial institutions in increasing economic growth through digitalization

The strategic role of sharia-based financial institutions in the digital era can provide solutions related to the above problems through sharia-based finance is one of the pillars in building a national economy from the micro and macro sides. From the micro side especially related to the development of Micro Small and Medium Enterprises and the role of micro small and medium enterprises in Islamic Micro Finance Institutions in advancing economic growth in Indonesia[38]. This role can be taken over by Islamic microfinance institutions in the form of Baitul Maal Wat Tamwil (BMT), Sharia Rural Banks (BPRS) and Islamic financial service cooperatives. with financial technology support such as third-party payment systems, Peer-to-Peer (P2P) Lending. Peer-to-Peer Lending and Crowdfunding and supported by easy access by the public to Islamic microfinance institutions can further enhance distribution of financing to the poor that cannot be reached by Islamic financial institutions in the city so that in the end it can increase people's income which indirectly impacts on economic growth. Furthermore, from the macro side, it is vital Islamic banking to drive the real sector at a higher level with the support of IT (Information Technology) and digitalization to be able to serve customers without place and time restrictions so as to increase the market share of Islamic financial institutions that have an effect on increasing production and adding material by producers. This can encourage producers to open jobs that automatically encourage income (income) and minimize the negative effects of unemployment as a macro problem.

\section{Conclusions}


The role of Islamic Financial Institutions in the digital age can be maximized by technological transformation whose purpose is to support performance, increase efficiency and productivity, which in turn will support the profitability performance of Islamic financial institutions. High-level technology adoption in Islamic financial institutions not only contributes to economic growth but also more equitable economic distribution. The principle of business activity in sharia economics places economic aspects and humanities aspects in a balanced way, expected to create a financial system that is not merely profit-oriented but also considers humanitarian aspects. Awareness of the public using Islamic financial business needs to be built, which of course must be followed by improving the quality of Islamic financial services and easy access to finance for the wider community through renewable financial technology so that the quality of Islamic finance in developing the national economy can continue to be optimized.

Acknowledgments. We thank all parties involved in the preparation of this paper for their assistance and participation so that this paper can be completed. We hope that this paper will benefit all.

\section{References}

[1] E. Ansong and R. Boateng, "Surviving in the digital era-business models of digital enterprises in a developing economy," Digit. Policy, Regul. Gov., vol. 21, no. 2, pp. 164-178, 2019.

[2] A. Maulidizen and M. T. Mohammad, "A Critical Analysis Of Islamic Economic Opportunities And Challenges In Globalizational Era," Share J. Ekon. dan Keuang. Islam, vol. 7, no. 2, 2018.

[3] A. Mashdurohatun, "Tantangan Ekonomi Syariah Dalam Menghadapi Masa Depan," J. Din. Huk., 2011.

[4] A. Ansori, "Digitalisasi Ekonomi Syariah,” Islam. J. Ekon. Islam, 2016.

[5] A. Barata, "Strengthening National Economic Growth Aand Equitable Income Through Sharia Digital Economy In Indonesia," J. Islam. Monet. Econ. Financ., vol. 5, no. 1 SEArticles, May 2019.

[6] M. P. Rizki and F. Fakhruddin, "Intermediasi Perbankan Syariah Terhadap Pertumbuhan Ekonomi Indonesia," J. Ekon. dan Kebijak. Publik Indones., vol. 2, no. 1, pp. 42-55, 2015.

[7] M. S. Salleh, "Contemporary Vision of Poverty and Islamic Strategy for Poverty Alleviation," SAGE Open, 2017.

[8] J. Boukhatem and F. Ben Moussa, "The effect of Islamic banks on GDP growth: Some evidence from selected MENA countries," Borsa Istanbul Rev., vol. 18, no. 3, pp. 231247, 2018.

[9] B. Baidhowi, "Sharia Banking Opportunities and Challenges in the Digital Era," in 1st International Conference on Indonesian Legal Studies (ICILS 2018), 2018.

[10] S. Makhmudah, "Dinamika dan Tantangan Masyarakat Islam di Era Modernisasi," J. Lentera Kaji. Keagamaan, Keilmuan dan Teknol., vol. 1, no. 2, pp. 242-259, 2015.

[11] J. Growiec, "The Digital Era, Viewed From a Perspective of Millennia of Economic Growth," Coll. Econ. Anal. SGH-Working Pap., no. 34, 2018.

[12] A. El-Galfy and K. A. Khiyar, "Islamic banking and economic growth: A review," J. Appl. Bus. Res., 2012. 
[13] K. Johnson, "The role of Islamic banking in economic growth," 2013.

[14] M. Abduh and M. Azmi Omar, "Islamic banking and economic growth: the Indonesian experience," Int. J. Islam. Middle East. Financ. Manag., 2012.

[15] P. Imam and K. Kpodar, "Islamic banking: Good for growth?," Econ. Model., 2016.

[16] A. S. Rusydiana, "Developing Islamic financial technology in Indonesia," Hasanuddin Econ. Bus. Rev., vol. 2, no. 2, pp. 143-152, 2018.

[17] Muhamad Mujahidin, "Opportunities and Challenges of Sharia Technology Financials in Indonesia," Munich Pers. RePEc Arch. Pap., 2019.

[18] E. Arvian Firmansyah and M. Anwar, Islamic Financial Technology (Fintech): Its Challenges And Propect. 2019.

[19] M. U. Chapra, Islam and Economic Development. 2019.

[20] R. Muttaqin, "Pertumbuhan Ekonomi dalam Perspektif Islam," Maro, vol. 1, no. 2, pp. $117-122,2018$.

[21] D. B. Kusuma, "Economic Development In An Islamic Perpective," in International Conference on Business and Economics, 2010, pp. 5-6.

[22] T. C. W. Lin, "Infinite Financial Intermediation.," Wake Forest Law Rev., 2015.

[23] P. Schueffel, "Taming the Beast: A Scientific Definition of Fintech," J. Innov. Manag., 2017.

[24] Lenny Sanicola, "What is FinTech?," Huffington Post, 2017.

[25] K. Leong and A. Sung, "FinTech (Financial Technology): What is It and How to Use Technologies to Create Business Value in Fintech Way?," Int. J. Innov. Manag. Technol., vol. 9, no. 2, pp. 74-78, 2018.

[26] K. S. Aldridge, I., Real-Time Risk: What Investors Should Know About Fintech, HighFrequency Trading and Flash Crashes. Hoboken: Wiley, 2017.

[27] Sugiyono, "Metode Penelitian Kuantitatif, Kualitatif Dan R\&D," Bandung: Alfabeta. CV. Alfabeta, p. 361, 2012.

[28] M. I. Bangsawan, "Eksistensi Ekonomi Islam (Studi Tentang Perkembangan Perbankan Syariah di Indonesia),” Law Justice, vol. 2, no. 1, pp. 24-34, 2017.

[29] I. Muzdalifa, I. A. Rahma, and B. G. Novalia, "Peran Fintech Dalam Meningkatkan Keuangan Inklusif Pada UMKM Di Indonesia (Pendekatan Keuangan Syariah), J. Masharif al-Syariah J. Ekon. dan Perbank. Syariah, vol. 3, no. 1, 2018.

[30] M. Nizar, Teknologi Keuangan (Fintech) : Konsep dan Implementasinya di Indonesia, vol. 5. 2017.

[31] A. M. Amran, R. A. Rahman, S. N. S. Yusof, and I. S. Mohamed, "The current practice of Islamic microfinance institutions' accounting information system via the implementation of mobile banking," Procedia-social Behav. Sci., vol. 145, pp. 81-87, 2014.

[32] Q. Gaumer, S. Mortier, and A. Moutaib, "Financial institutions and cyber crime Between vulnerability and security," FSR Financ., p. 45, 2016.

[33] E. W. Waiganjo, E. Mukulu, and J. Kahiri, "Relationship between strategic human resource management and firm performance of Kenya's corporate organizations," Int. J. Humanit. Soc. Sci., vol. 2, no. 10, pp. 62-70, 2012.

[34] T. Febriana, "Studi Penerapan Inovasi Teknologi Informasi dengan Metode Technology Watch and Competitive Intelligent (Tw-Ci)," ComTech Comput. Math. Eng. Appl., vol. 5, no. 1, pp. 350-360, 2014.

[35] A. N. Hidayah and I. A. Kartini, "Peranan Bank Syariah dalam Sosialisasi dan Edukasi Masyarakat Tentang Kemanfaatan Produk dan Jasa Perbankan Syariah," J. Kosmik Huk., vol. 16, no. 1, 2016. 
[36] A. Soleh, "Pertumbuhan Ekonomi dan Kemiskinan di Indonesia," Ekombis Rev., vol. 2, no. 2, 2014.

[37] R. Q. Syahriar, "Peran Teknologi Informasi Dalam Pengentasan Kemiskinan di Indonesia," J. Sains dan Teknol. Indones., vol. 8, no. 3, 2012.

[38] H. Santoso and Y. Siyamto, "Investasi Dan Dorongan Pertumbuhan Ekonomi Bisnis Mikro Islam Di Indonesia,” J. Ilm. Ekon. Islam, vol. 2, no. 01, 2016. 